\title{
Simulasi Penerapan Multiple Queue Multiple Server Pada Antrian Bank Dengan Metode Discrete Event Simulation
}

\author{
${ }^{1)}$ Saidi Ramadan Siregar \\ STMIK Budi Darma Medan, JI. Sisingamangaraja No. 338 Medan, Sumatera Utara, Indonesia \\ E-mail : saidiramadan89@gmail.com \\ 2) Pristiwanto \\ STMIK Budi Darma Medan, JI. Sisingamangaraja No. 338 Medan, Sumatera Utara, Indonesia \\ E-mail : 4nt0.82@gmail.com
}

\begin{abstract}
ABSTRAK
Simulasi merupakan proses implementasi model menjadi program komputer (software) dan mengeksekusi software tersebut sedemikian rupa sehingga perilakunya menirukan atau menyerupai sistem nyata tertentu. Tujuan dari dibuatnya simulasi antara lain sebagai pelatihan (training), studi perilaku sistem (behavior), dan permainan (games). Salah satu contoh kejadian pada kehidupan nyata yang dapat disimulasikan adalah simulasi antrian bank.

Terdapat banyak model antrian yang dapat diterapkan pada simulasi antrian bank, salah satunya yaitu Multiple Queue Multiple Server (MQMS) yang dapat diartikan sebagai satu antrian dengan beberapa pelayan (teller). Untuk membuat sebuah simulasi antrian bank MQMS dibutuhkan perencanaan atau skenario, di mulai dari proses kedatangan nasabah ke bank, proses antrian nasabah, proses pelayanan nasabah, sampai proses kepergian nasabah dari bank.

Berdasarkan teknik atau metodologi simulasi maka metode yang paling tepat untuk mensimulasikan antrian yaitu Simulasi Kejadian Diskret (Discrete Event Simulation). Discrete Event Simulation (DES) adalah suatu simulasi dimana perubahan statusnya terjadi pada titik-titik diskrit dalam waktu yang dipicu oleh kejadian (event). Pada DES, suatu kejadian (event) akan mempengaruhi kejadian (event) yang akan berlangsung selanjutnya.
\end{abstract}

Kata Kunci: Simulasi, Multiple Queue Multiple Server (MQMS), Simulasi Kejadian Diskret (Discrete Event Simulation), DES

\section{PENDAHULUAN}

Lambatnya pelayanan pada suatu instansi mengakibatkan banyaknya jumlah antrian yang terjadi. Misalnya antrian nasabah Bank sering terjadi penumpukan nasabah pada garis antrian. Ini disebabkan karena kurangnya analisa oleh pihak Bank dalam masalah layanan nasabah Bank. waktu kedatangan, waktu pelayanan per setiap nasabah adalah salah satu masukan penting yang diberikan kepada pengelola Bank.

Dalam hal ini untuk mendapatkan waktu kedatangan, lama pelayanan yang akurat agar lebih efektif dan efisien maka sistem komputer yang tepat menyelesaikan masalah ini adalah menggunakan simulasi. simulasi merupakan merancang model sistem nyata dan melakukan eksperimen dengan model untuk tujuan memahami perilaku sistem ${ }^{[19]}$. Simulasi dapat diterapkan untuk sistem kecil dan besar. mengeksekusi software tersebut sedemikian rupa sehingga perilakunya menirukan atau menyerupai sistem nyata tertentu.
Jadi simulasi adalah proses merancang model dari suatu sistem yang sebenarnya, mengadakan percobaan-percobaan terhadap model tersebut dan mengevaluasi hasil percobaan tersebut. Tujuan dari dibuatnya simulasi antara lain sebagai pelatihan (training), studi perilaku sistem (behavior), dan permainan (game) ${ }^{[6]}$. Salah satu contoh kejadian pada kehidupan nyata yang dapat disimulasikan adalah simulasi antrian Bank.

Adapun perumusan masalahnya, antara lain: 1). Bagaimana menggunakan disiplin antrian FCFS (First Come First Service) yang diterapkan pada model antrian Multiple Queue Multiple Sever (MQMS) ?, 2). Bagaimana merancang sebuah sistem simulasi yang dapat mensimulasikan kejadian (event) mulai dari kedatangan, antrian, pelayanan dan kepergian nasabah dengan sistem antrian Multiple Queue Multiple Server dengan metode Discrete Event Simulation (DES)? 3).Bagaimana meng-implementasikan metode Discrete Event Simulation (DES) pada simulasi yang akan dibuat? 
Manfaat dari Penelitian ini adalah Dapat menghasilkan sebuah simulasi penerapan Multiple Queue Multiple Server (SQMS) pada antrian bank dengan metode Discrete Event Simulation (DES). Dan Dapat menunjukkan keadaan antrian dan pelayanan nasabah dengan total lama antrian pernasabah dan total waktu tunggu pernasabah serta Dapat digunakan untuk sistem pengambilan keputusan (SPK) untuk pihak pengelola Bank dalam menganalisa sistem antrian pelayanan nasabah (customer) bank.

Simulasi merupakan suatu model pengambilan keputusan dengan mencontoh atau mempergunakan gambaran sebenarnya dari suatu sistem kehidupan dunia nyata tanpa harus mengalaminya pada keadaan yang sesungguhnya ${ }^{[22]}$.

Sebuah kegiatan usaha untuk menyalin fitur, tampilan, dan karateristik sebuah sistem nyata disebut simulasi. Suatu teori abstrak sistem dapat direpresentasikan dengan beberapa bantuan sistem komputer dan beberapa perangakat lunak (software) yang berkontribusi dalam penanganan model.

Simulasi adalah proses implementasi model menjadi program komputer (software) atau rangkaian elektronik dan mengeksekusi software tersebut sedemikian rupa sehingga perilakunya menirukan atau menyerupai sistem nyata (realitas) tertentu untuk tujuan mempelajari perilaku (behavior) sistem, pelatihan (training), atau permainan (game) tanpa melibatkan sistem nyata tersebut.

Dari keterangan diatas, dapat disimpulkan secara umum bahwa pengertian simulasi adalah pemodelan dari suatu proses atau sistem sedemikian rupa sehingga model menyerupai sistem nyata dengan segala event yang terjadi di dalamnya.

Simulasi merupakan merancang model sistem nyata dan melakukan eksperimen dengan model untuk tujuan memahami perilaku sistem $^{[19]}$.

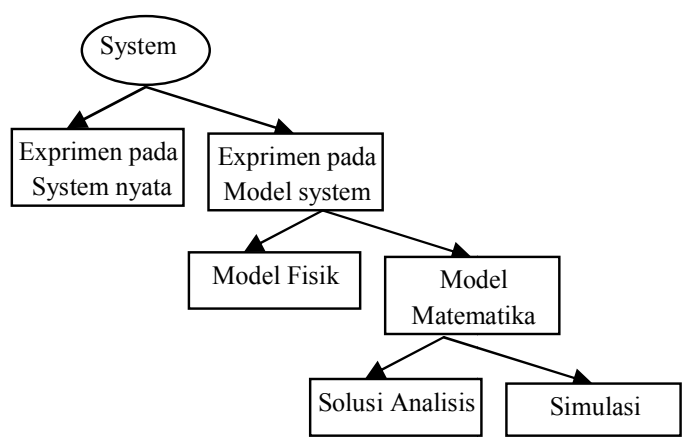

Gambar 1 Model Sistem Nyata ${ }^{[19]}$

Simulasi merupakan pemodelan suatu proses atau sistem sedemikian rupa sehingga model menyerupai sistem nyata dengan segala event yang terjadi didalamnya. kata pemodelan dan simulasi menunjukkan kompleksitasnya aktivitas-aktivitas yang berhubungan dengan pembentukan model sistem nyata dan mensimulasikannya pada komputer $^{[1]}$.

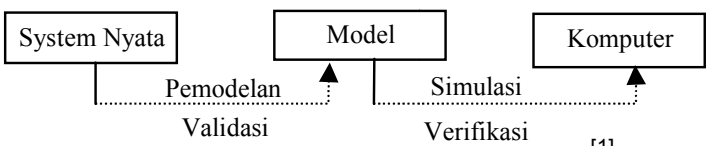

Gambar 2. Simulasi pada Komputer ${ }^{[1]}$

Tipe model simulasi diantaranya yaitu Statis, dinamis, stokastik, deterministik, kejadian kontinu, kejadian diskrit ${ }^{99}$.

Model simulasi ini dapat digunakan untuk menggambarkan sistem yang bersifat statis maupun dinamis. Model simulasi statis adalah model yang menggambarkan sistem dimana keadaannya tidak dipengaruhi waktu. Model simulasi dinamis adalah model simulasi yang keadaan sistemnya berubah dipengaruhi waktu.

Model simulasi ini dapat menggambarkan kejadian yang bersifat parsial atau tidak mengandung unsur probabilitas (deterministik), maupun yang bersifat tidak pasti dengan mengandung unsur probabilitas yang ditandai dengan adanya kerandoman input dari model (stokastik).

Adapun dari tipe model system simulasi Discrete Event Simulation Fourt Edition dalam Handbook yang keedisi empat dapat digambarkan sebagai berikut ${ }^{[9]}$ :

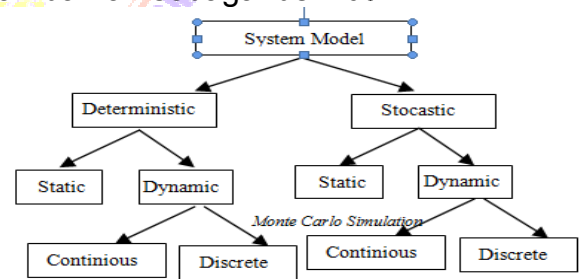

Gambar 3. Model Sistem Simulasi ${ }^{[y]}$

Pelayanan terbaik merupakan hal utama yang harus diberikan oleh produsen kepada konsumen dalam memenuhi kebutuhan sehingga konsumen merasa puas (costumer satisfaction). Terjadinya antrian merupakan salah satu bentuk contoh pelayanan yang kurang baik. Karena hal ini membuat konsumen menunggu untuk dilayani ${ }^{[4]}$. Didalam antiran yang baik harus mempertimbangkan estimasi nilai rata-rata lamanya pelanggan (costumer) menunggu dalam garis antrian dan berapa lama waktu yang digunakan untuk melayani pelanggan serta memperhitungkan server berapa lama estimasi mengganggur ${ }^{[9]}$. Misalnya antrian terjadi pada loket bioskop, loket kereta api, 
loket-loket pada bank, dermaga di pelabuhan, loket jalan tol, pelabuhan udara, telepon jarak jauh, tempat praktek dokter, loket stadion, pompa minyak dan banyak lagi ang lainnya ${ }^{[4]}$.

Sebuah aktifitas dimana pelanggan (customer) untuk memeperoleh layanan, antrian terjadi karena terbatasnya sumber daya pelayanan yang pada kenyataannya disebabkan karena adanya faktor ekonomi yang membatasi yang selalu terkait dengan berapa jumlah server yang harus disediakan ${ }^{[2]}$.

Antrian adalah keadaan dimana seorang individu harus menunggu giliran untuk mendapatkan jasa pelayanan. Pelayanan antrian tersebut timbul karena banyaknya individu yang membutuhkan jasa pelayanan pada waktu yang bersamaan. Sebagai akibatnya seseorang harus menunggu beberapa waktu dalam suatu antrian untuk menunggu giliran agar mendapatkan pelayanan, oleh karena itu sistem antrian dirancang lebih efesien dengan menggunakan teori antrian ${ }^{[15]}$.

Bentuk kombinasi proses kedatangan dan pelayanan pada umumnya dikenal sebagai standar universal disebut Notasi Kendall ${ }^{[7,13]}$.

(a/b/c):(/d/e/f) Dimana simbol a,b,c,d,e dan $f$ merupakan unsur-unsur dasar dari model baris antrian :

a: Distribusi Kedatangan

b: Distribusi waktu Pelayanan

c: Jumlah Pelayanan

d: Disiplin pelayanan, serperti FCFS, LCFS, SIRO.

e: Jumlah maksimum yang diizinkan dalam sistem.

f: Jumlah pelanggan yang ingin memasuki sistem dalam sumber.

Model ini menyatakan bahwa distribusi kedatangan Poisson dan waktu pelayanan Eksponensial, jumlah pelayanan adalah 1, disiplin pelayanannya adalah FIFO, tak berhingga jumlah langganan boleh masuk dalam sistem antrian, dan sumber kedatangan tak berhingga. Berdasarkan analisis terhadap pola kedatangan dari suatu kasus pertibaan secara umum, diketahui bahwa peluang adanya satuan secara acak dalam antrian pada waktu t adalah :

$$
\operatorname{Pn}(\mathrm{t})=\frac{(\mu t)^{\mathrm{n}} \mathrm{e}^{-\mu \mathrm{t}}}{n !}
$$

Yang merupakan suatu distribusi Poisson dengan parameter ut. Dalam keadaan stationer atau steady state, maka $\mathrm{Pn}(\mathrm{t})=\mathrm{Pn}$ untuk semua $\mathrm{t}$, artinya $P n$ tidak terikat pada waktu atau $d P n / d t=0 \quad$ (Faradhika Arwindy,2014).
Sehingga dapat dikatakan suatu kedatangan pada suatu sistem antrian adalah saling independen dan bervariasi secara acak sepanjang waktu. Berdasarkan analisis terhadap pola pelayanan dari suatu kasus pelayanan secara umum, diketahui waktu pelayanan tiap satuan dapat ditulis sebagai berikut :

$$
\begin{gathered}
f(t)=\mu e^{-\mu t} \\
\text { Yang merupakan suatu distribusi } \\
\text { Eksponensial dengan parameter } \mu .
\end{gathered}
$$
Berdasarkan karakteristik tersebut, maka untuk model ini dapat diberikan beberapa ukuran dasar antrian sebagai berikut:

1. Intensitas Lalu Lintas

Dalam sistem pelayanan tunggal intensitas lalu lintas atau dapat juga dikatakan sebagai peluang bahwa sistem antrian adalah sibuk disimbolkan dengan $\rho$ yakni hasil bagi antara tingkat kedatangan $(\lambda)$ dengan tingkat pelayanan $(\mu)$ yang dapat dituliskan sebagai:

$$
\rho=\frac{\lambda}{\mu}
$$

Bila $\rho$ merupakan peluang bahwa sistem antrian adalah sibuk, maka tentu $1-\rho$ merupakan peluang bahwa sistem tidak dalam keadaan sibuk pada sebarang waktu.

2. Waktu Rata-rata dalam Sistem

$$
E\left(n_{t}\right)=\frac{\lambda}{\mu-\lambda}=\frac{\rho}{1-\rho}
$$

1. Waktu Rata-rata dalam Antrian

$$
E\left(n_{\omega}\right)=\frac{\lambda}{\mu-\lambda}-\frac{\lambda}{\mu}=\frac{x^{2}}{\mu(\mu-\lambda)}
$$

2. Jumlah Rata-rata dalam Sistem

$$
E\left(T_{t}\right)=\frac{E\left(n_{t}\right)}{\lambda}=\frac{\frac{\lambda}{\mu-\lambda}}{\lambda}=\frac{1}{\mu-\lambda}
$$

3. Jumlah Rata-rata dalam Antrian

$$
E\left(T_{\omega}\right)=\frac{E\left(n_{\omega}\right)}{\lambda}=\frac{\frac{x^{2}}{\mu(\mu-\lambda)}}{\lambda}=\frac{\lambda}{\mu(\mu-\lambda)}
$$

Karakteristik dari model ini adalah pelayanan atau saluran ganda, pola kedatangan Poison, pola pelayanan Exponensial dan antrian tak berhingga. Untuk kedatangan model ini, dapat diberikan beberapa ukuran dasar antrian sebagai berikut:

1. Peluang Masa Sibuk

$$
f(b)=P[n \geq c]=\frac{\rho^{c} \mu c}{c !(\mu c-\lambda)}\left(P_{0}\right)
$$

Sementara itu, harga-harga $f(b)$ dapat dicari dalam tabel peluang masa sibuk untuk harga $\rho$ dan $c$ yang sesuai.
2. $E\left(n_{t}\right)=f(b)\left(\frac{\lambda}{c \mu-\lambda}\right)+\frac{\lambda}{\mu}$
3. $E\left(n_{\omega}\right)=f(b)\left(\frac{\lambda}{c \mu-\lambda}\right)$ 
ISSN : 2548-6985

4. $E\left(T_{t}\right)=f(b)\left(\frac{\lambda}{c \mu-\lambda}\right)+\frac{1}{\mu}$

5. $E\left(T_{\omega}\right)=f(b)\left(\frac{1}{c \mu-\lambda}\right)$

Uji Kecukupan Data adalah Dasar pertimbangan dalam menentukan besarnya sampel yang ditarik dari suatu populasi memerlukan pemikiran yang hati-hati (Faradhika Arwindy,2014). Untuk itu dilakukan uji kecukupan data untuk menentukan besar sampel yang dibutuhkan dengan persamaan seperti berikut:

$N^{-1}=\left(\frac{\left(\frac{k}{s} \sqrt{N \sum x_{i}^{2}-\left(\sqrt{x_{i}}\right)^{2}}\right)}{\sum x_{i}}\right)^{2}$

Keterangan :

$\mathrm{N}^{1}$ : Jumlah pengamatan yang seharusnya dilakukan.

$\mathrm{k}$ : tingkat kepercayaan dalam pengamatan.

$\mathrm{s}$ : tingkat ketelitian dalam pengamatan.

$\mathrm{N}$ : jumlah pengamatan yang sudah dilakukan. $\mathrm{x}_{\mathrm{i}}=$ data pengamatan.

Data pengamatan dianggap cukup apabila $\mathrm{N}^{1}$ lebih kecil dari $\mathrm{N}$.

\section{METOTODOLOGI PENELITIAN}

\begin{tabular}{|c|}
\hline Menentukan Masalah \\
\hline Merumuskan Masalah \\
\hline Mempelajari Literatur \\
\hline Mengumpulkan Data \\
\hline Menganalisa Data \\
\hline $\mathbf{7}$ \\
\hline Merancang Simulasi \\
\hline Membangun Sistem \\
\hline Menguji Sistem \\
\hline Menarik Kesimpualan \\
\hline
\end{tabular}

Gambar 4. Kerangka Kerja Penelitian (Frame Work)

\section{ANALISA DAN PEMBAHASAN}

Data diperoleh melalui hasil pengamatan langsung dengan mencatat jumlah kedatangan nasabah tiap jam dan waktu pelayanan tiap nasabah. Untuk data kedatangan nasabah disajikan pada Tabel 1, Tabel 2 dan Tabel 3

Tabel 1 Waktu Pengamatan Selasa, 1 Desember 2015

\begin{tabular}{|c|c|c|c|c|c|}
\hline \multirow{2}{*}{$\begin{array}{l}\mathbf{N} \\
\mathbf{0}\end{array}$} & \multirow{2}{*}{$\begin{array}{c}\text { Waktu } \\
\text { Kedatanga } \\
\mathbf{n} \\
\text { Nasabah }\end{array}$} & \multicolumn{3}{|c|}{ Mulai Melayani } & \multirow{2}{*}{$\begin{array}{c}\text { Selesai } \\
\begin{array}{c}\text { Melayan } \\
\text { i }\end{array} \\
\end{array}$} \\
\hline & & $\begin{array}{c}\text { Teller } \\
1\end{array}$ & $\begin{array}{c}\text { Teller } \\
2\end{array}$ & $\begin{array}{c}\text { Teller } \\
\mathbf{3} \\
\end{array}$ & \\
\hline 1 & $8: 00$ & 8.01 & & & $8: 03$ \\
\hline 2 & 8:00 & & 8.01 & & 8:01 \\
\hline 3 & 8:01 & & & 8.02 & 8:02 \\
\hline
\end{tabular}

\begin{tabular}{|l|l|l|l|l|l|}
4 & $8: 01$ & & 8.02 & & $8: 03$ \\
\hline
\end{tabular}

\section{Selasa, 1 Desember 2015}

Hasil penelitian terhadap kedatangan nasabah bank pada Selasa, 1 Desember 2015 digunakan untuk menyusun kedatangan pelanggan per interval waktu 2 menit.

Tabel 2 Antrian dan Kedatangan

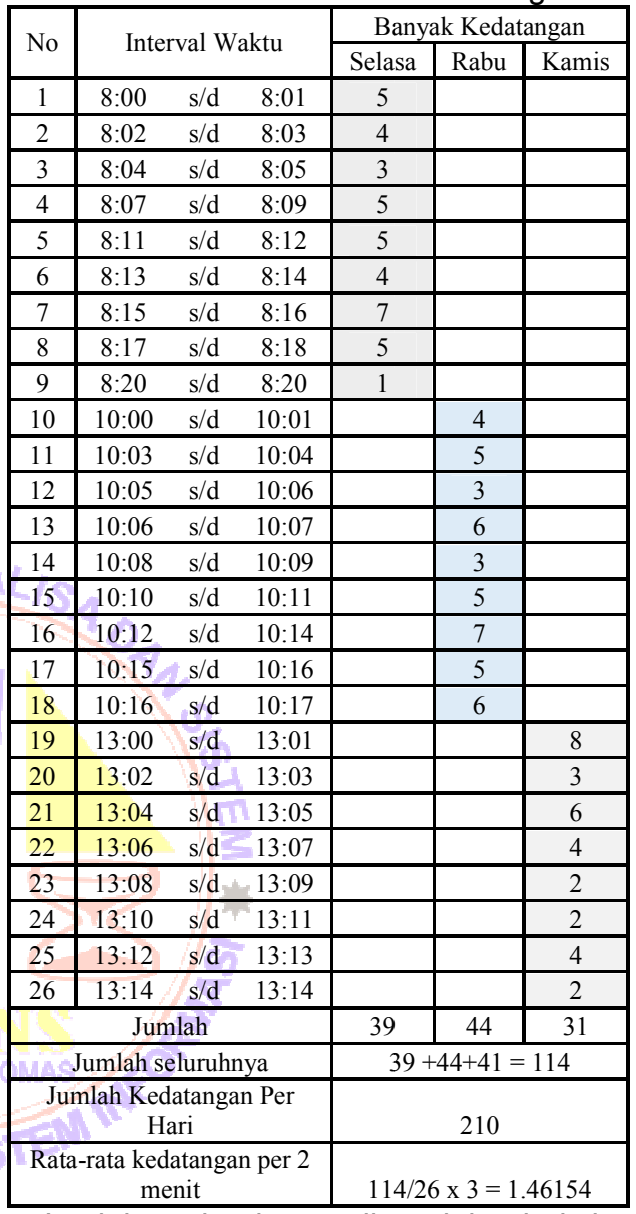

Jumlah seluruhnya diperoleh dari hasil penjumlahan banyaknya kedatangan dalam per hari dengan rata-rata 17 menit. 8:00-8:20, 10:00-10:17, dan 13:00-13:14 yaitu $39+44+41$ $=114$. Jumlah kedatangan per hari diperoleh dari 7 jam hari kerja dikali dibagi dengan 2 menit yaitu $7 \times 60$ menit $/ 2$ menit $=210$ menit. 210 sama dengan $210 \times 1$ orang $=210$ orang per hari.

Implementasi Aplikasi Simulasi Penerapan Multiple Queue Multiple Server (MQMS). Pada Antrian Bank dengan Metode Discrete Event Simulation ini mencakup spesifikasi kebutuhan perangkat keras (hardware) dan spesifikasi perangkat lunak (software).

Tampilan utama dari perangkat lunak simulasi ini dapat dilihat pada gambar berikut ini. Pada implementasi input data simulasi nilai yang diinput sesuai dengan tipe data yang dibuat dalam sistem. 
ISSN : 2548-6985

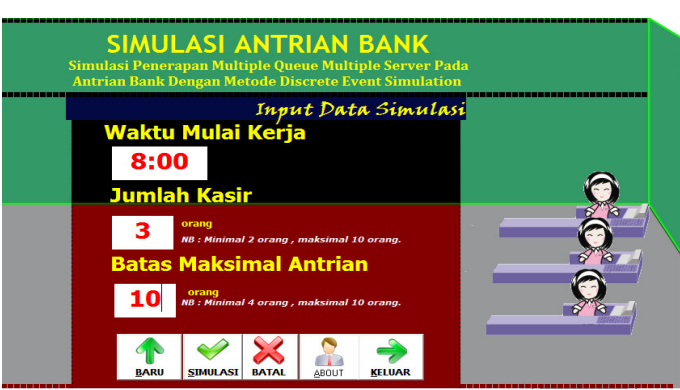

Gambar 5. Menu Aplikasi Antrian di Bank

Keterangan :

Pada main form terdapat textbox yang harus diisi seperti waktu mulai kerja. Misalnya dari input data untuk waktu diinput pada pukul mulai waktu kerja sekitar 08:00

a. Pada form main terdapat textbox yang harus diisi yaitu jumlah teller (antara 4 10 teller). Dalam implementasi ini data yang diinputkan sebanyak 3 Teller sesuai dengan jumlah Teller yang ada pada bank yang diteliti.

b. Pada form main terdapat textbox yang harus diisi yaitu dan batas maksimal antrian (minimal 4-10 orang) dalam satu jalur antiran. Dalam implementasi ini data yang diinputkan sebanyak 10 orang. Artinya jumlah nasabah maksimal dalam satu jalur antrian sebanyak 10 nasabah.

c. Pada form ini terdapat juga tombol Simulasi, untuk menuju ke form simulasi, tombol about untuk menuju ke form about dan tombol keluar untuk keluar dari sistem.

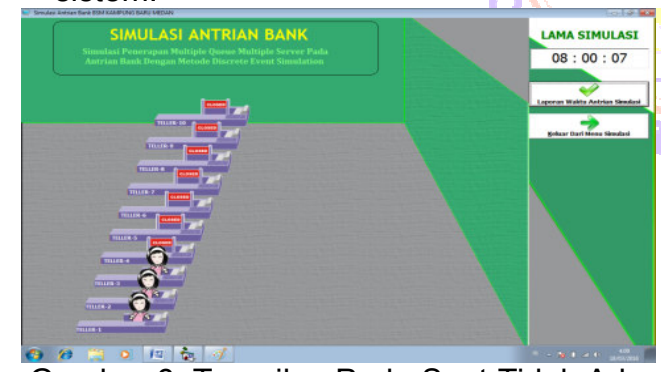

Gambar 6. Tampilan Pada Saat Tidak Ada Nasabah Dalam Sistem

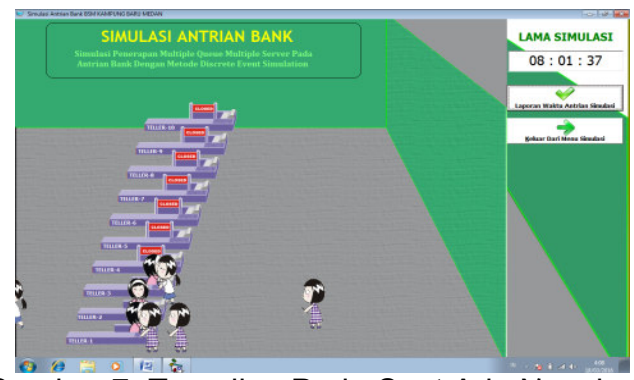

Gambar 7. Tampilan Pada Saat Ada Nasabah Dalam Sistem

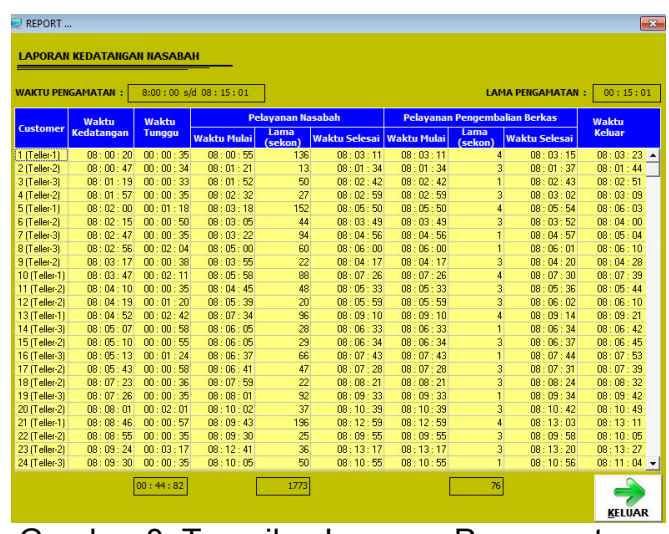

Gambar 8. Tampilan Laporan Pengamatan Terhadap Sistem

\section{PENGUJIAN}

Didalam proses validasi data simulasi ditinjau beberapa hal yang menyerupai perilaku (behavior) pengamatan langsung adalah sebagai berikut :

1.Nasabah yang ke-.

2.Waktu kedatangan Nasabah ke-.

3.Nasabah ke- menuju teller yang ke-.

4.Waktu keluar nasabah ke- dari sistem.

Tabel 3. Validasi Hasil Pengamatan Dan Hasil Simulasi

\begin{tabular}{|c|c|c|c|c|c|c|c|}
\hline \multicolumn{3}{|c|}{ Hasil Pengamatan } & \multicolumn{4}{|c|}{ Hasil Simulasi } \\
\hline KNP & WKNP & TP & WKeNP & KNS & WKNS & TS & WKeNS \\
\hline 1 & $8: 00$ & 1 & $8: 03$ & 1 & $8: 00: 20$ & 1 & $8: 03: 23$ \\
\hline 2 & $8: 00$ & 2 & $8: 01$ & 2 & $8: 00: 47$ & 2 & $8: 01: 44$ \\
\hline 3 & $8: 01$ & 3 & $8: 02$ & 3 & $8: 01: 19$ & 3 & $8: 02: 51$ \\
\hline 4 & $8: 01$ & 2 & $8: 03$ & 4 & $8: 01: 57$ & 2 & $8: 03: 09$ \\
\hline 5 & $8: 02$ & 1 & $8: 06$ & 5 & $8: 02: 00$ & 1 & $8: 06: 03$ \\
\hline 6 & $8: 02$ & 2 & $8: 04$ & 6 & $8: 02: 15$ & 2 & $8: 04: 00$ \\
\hline 7 & $8: 02$ & 3 & $8: 05$ & 7 & $8: 02: 47$ & 3 & $8: 05: 04$ \\
\hline 8 & $8: 02$ & 3 & $8: 06$ & 8 & $8: 02: 56$ & 3 & $8: 06: 10$ \\
\hline 9 & $8: 03$ & 2 & $8: 04$ & 9 & $8: 03: 17$ & 2 & $8: 04: 28$ \\
\hline 10 & $8: 03$ & 1 & $8: 07$ & 10 & $8: 03: 47$ & 1 & $8: 07: 39$ \\
\hline 11 & $8: 04$ & 2 & $8: 05$ & 11 & $8: 04: 10$ & 2 & $8: 05: 44$ \\
\hline 12 & $8: 04$ & 2 & $8: 06$ & 12 & $8: 04: 19$ & 2 & $8: 06: 10$ \\
\hline 13 & $8: 05$ & 1 & $8: 09$ & 13 & $8: 04: 52$ & 1 & $8: 09: 21$ \\
\hline 14 & $8: 05$ & 2 & $8: 06$ & 14 & $8: 05: 07$ & 3 & $8: 06: 42$ \\
\hline 15 & $8: 05$ & 2 & $8: 07$ & 15 & $8: 05: 10$ & 2 & $8: 06: 45$ \\
\hline 16 & $8: 05$ & 3 & $8: 07$ & 16 & $8: 05: 13$ & 3 & $8: 07: 53$ \\
\hline 17 & $8: 06$ & 1 & $8: 08$ & 17 & $8: 05: 43$ & 2 & $8: 07: 39$ \\
\hline 18 & $8: 07$ & 2 & $8: 09$ & 18 & $8: 07: 23$ & 2 & $8: 08: 32$ \\
\hline 19 & $8: 07$ & 3 & $8: 09$ & 19 & $8: 07: 26$ & 3 & $8: 09: 42$ \\
\hline 20 & $8: 08$ & 1 & $8: 10$ & 20 & $8: 08: 01$ & 2 & $8: 10: 49$ \\
\hline
\end{tabular}

Tabel 4. Perbedaan Hasil Pengamatan Dan Hasil Simulasi.

\begin{tabular}{|c|c|c|c|c|c|c|c|}
\hline \multicolumn{4}{|c|}{ Hasil Pengamatan } & \multicolumn{4}{|c|}{ Hasil Simulasi } \\
\hline KNP & WKNP & TP & WKeNP & KNS & WKNS & TS & WKeNS \\
\hline 13 & $8: 05$ & 1 & $8: 09$ & 13 & $8: 04: 52$ & 1 & $8: 09: 21$ \\
\hline 14 & $8: 05$ & 2 & $8: 06$ & 14 & 8:05:07 & 3 & $8: 06: 42$ \\
\hline 17 & $8: 06$ & 1 & $8: 08$ & 17 & 8:05:43 & 2 & $8: 07: 39$ \\
\hline
\end{tabular}




\begin{tabular}{|}
$\mid$\begin{tabular}{|c|c|c|c|c|c|c|c|}
\hline 18 & $8: 07$ & 2 & $8: 09$ & 18 & $8: 07: 23$ & 2 & $8: 08: 32$ \\
\hline 20 & $8: 08$ & 1 & $8: 10$ & 20 & $8: 08: 01$ & 2 & $8: 10: 49$ \\
\hline
\end{tabular} \\
\hline
\end{tabular}

Implementasi dan pengujian dapat disimpulkan dari pengamatan kegiatan sistem yang sebenarnya (observation) dengan hasil simulasi yang meniru tingkah laku dari dari pada sistem (behavior) memiliki perbandingan yang tidak terlalu jauh dari hasil simulasi dengan hasil pengamatan.

Berdasarkan pengujian yang sudah diimplementasikan diatas. Hasil simulasi memberikan rincian waktu lebih detail yaitu mulai dari pelanggan (customer)yang ke-i, waktu kedatangan nasabah, waktu menunggu nasabah, pelanggan mulai dilayani, pelayanan nasabah, waktu mulai pelayanan nasabah, lama pelayanan nasabah, waktu selesai pelayanan nasabah, waktu mulai pelayanan pengembalian berkas, lama pelayanan pengembalian berkas nasabah, waktu selesai pelayanan pengembalian berkas nasabah, dan waktu keluar nasabah dari sistem.

Adapun hasil yang tidak terlalu jauh hasil simulasi dengan pengamatan yang sudah diuraikan diatas mulai dari penyajian data pengamatan dan hasil simulasi yang diperoleh sebagai berikut:

1. Kedatangan Nasabah (KN)

Data Kedatangan Nasabah yang telah diuji dari sistem simulasi yang dibuat dengan pengamatan langsung (obersevation) menghasilkan persamaan sebesar $100 \%$.

2. Waktu kedatangan Nasabah ke-(WKN)

Data Waktu Kedatangan Nasabah keyang telah diuji dari sistem simulasi yang dibuat dengan pengamatan langsung (observation) menghasilkan persamaan sebesar $80 \%$

3. Teller (T)

Data Teller yang telah diuji dari sistem simulasi yang dibuat dengan pengamatan langsung (observation) menghasilkan persamaan sebesar $70 \%$.

4. Waktu Keluar Nasabah (WKeN)

Data Waktu Keluar Nasabah yang telah diuji dari sistem simulasi yang dibuat dengan pengamatan langsung (observation) menghasilkan persamaan sebesar $70 \%$.

Maka dapat dijumlahkan : $\mathrm{KN}+\mathrm{WKN}+\mathrm{T}$ + WkeN / 4 $=100 \%+80 \%+70 \%+70 \% / 4=$ $320 \% / 4=80 \%$.

Hasil pengujian simulasi dengan pengamatan memiliki kemiripan sebesar $80 \%$.

\section{KESIMPULAN}

1. Simulasi yang dihasilkan memiliki kemiripan sebesar $80 \%$ dengan pengamatan yang dilakukan selama penelitian.

2. Hasil simulasi memberikan rincian waktu lebih detail yaitu mulai dari waktu kedatangan, waktu menunggu, mulai dilayani, lama pelayanan, waktu selesai pelayanan, waktu mulai pelayanan pengembalian berkas, lama pelayanan pengembalian berkas, waktu selesai pelayanan pengembalian berkas,dan waktu keluar nasabah dari sistem.

3. Semakin banyak teller yang dibuka maka jumlah nasabah dalam system antrian akan semakin sedikit.

\section{DAFTAR PUSTAKA}

1. Abdurrozzaq. (2009). "Pengembangan Model Simulasi Untuk Perencanaan Kapasitas Unit Perawatan Intensif (ICU).": Volume 6 No.4 Halaman. 65.

2. Alfi. (2009). "Simulasi Antrian Satu Channel Dengan Tipe Kedatangan Berkelompok." Jurnal IImiah Generic Volume. 4 No. 1 Halaman 50-51.

3. Alka. (2011). "A Comparison Between FCFS and Mixed Schedulling.": IJCST Vol.2, Issue 2 Page 77-78.

4. Elis. (2015). "Model Antrian Multi Server Dengan Gangguan Pelayanan Dengan Pola Kedatangan Berkelompok.": Volume IX No 1 Halaman 222-223.

5. Emmanuel (2011). "Analysis of MultiServer Single Queue System With Multiple Phases.": Pak.j.stat.oper.res. Vol.VII No.2.

6. Falah. (2013). "Simulasi Antrian Sistem Pelayan Nasabah (Studi Kasus: Bank X.") : JSSP Vol. 6, No.1 Halaman 1Siti. (2014). "Analisis Sistem Antrian Pelayanan Nasabah Di PT. BANK Negara Indonesia (Persero).Tbk Kantor Cabang Utama USU.", Saintia Vol.02, No 03. Halaman 278.

7. Feri. (2013). "Aplikasi Teori Antrian dan Simulasi Pada Pelayanan Teller Bank.": UNNES Journal Of Mathematics 2 (1), Halaman 19.

8. Gustri. (2012). "Perancangan Sistem Simulasi Antrian Kenderaan Bermotor Pasa Pengisian Bahan Bakar Umum (SPBU) Menggunakan Metode Distribusi Eksponensial.": JELIKU Vol 1 No.2 Hal 105.

9. Jerry. (2015). "Discrete-Event System Simulation.",Prentice Hall International Series in Industrial and System Enginering. Page 377. 
10. Manish. (2012). "An Improved FCFS (IFCFS) Disk Schedulling Algorithm.": Volume 47-No.13 page 21.

11. Martha. (2012). "Analisi Sistem Antrian Pada Loket Pembayaran PT. PLN(PERSERO) Area Bali Selatan Rayon Kuta.": Vol.1 No.1 Halaman 6.

12. Maria. (2014). "Urban Simulation Models: Contributions as Analysis-Methodology in a Project of Urban Renewal.".

13. Putriaji. (2014). "Aplikasi Matrix Laboratory Untuk Perhitungan Sistem Antrian Dengan Server Tunggal dan Majemuk.": Scientific Journal of Information, Vol. 1 No.1 Halaman 66.

14. Rukhsar. (2015). "Analysis Of Priority Schedulling Algorithm On The Basis Of FCFS \& SJF For Similiar Priority Jobs.":IJCSMC, Vol. 4, Issue 9 Page 324 \&326.

15. Rusdy. (2010). "Model Antrian FCFS Sebagai Bentuk Pelayanan Yang Adil Berbasis Program Pascal.": Jurnal Dinamika Informatika Volume 4, Nomor 2 Halaman 82.

16. Salaki (2012). "Deskripsi Sistem Antrian Pada Klinik Dokter Spesialis Penyakit Dalam.": Vol. 12 No.1 Halaman 73.

17. Siregar. (2013). "Analisis Waktu Antar Kerusakan Mesin Electric Motor Menggunakan Metode Failure Finding Interval (Studi Kasus di PT. XYZ).": Vol. 1, No.1 Halaman 21.

18. Siebers. (2010). "Discrete Event Simulation is Dead, Long Live AgentBased Simulation.": Journal of Simulation Vol. 4 No 3 Page 207.

19. Syed. (2014). "Simulaition: Analysis of Single Server Queuing Model":IJIT Vol.3, No.3 Page: $47,48$.

20. Tiny. (2008). "Pemodelan Sebagai Sarana Dalam Mencapai Solusi Optimal.": Volume 8 No 3 Hal 184.

21. Wiley. (2016). "Simulation Modeling And Arena.":Books Second Edition.

22. Yani. (2012). "Simulasi Dan Pemodelan Sistem Antrian Pelanggan Di Loket Pembayaran Rekening XYZ Semarang.", Volume 3 No. 3 Halaman 2. 